University of Wollongong

Research Online

Faculty of Business - Papers (Archive)

Faculty of Business and Law

$1-1-2012$

HR on the line: Human resource managers' contribution to organisational value and workplace performance

Paul J. Gollan

Macquarie University, pgollan@uow.edu.au

Follow this and additional works at: https://ro.uow.edu.au/buspapers

Part of the Business Commons

Research Online is the open access institutional repository for the University of Wollongong. For further information contact the UOW Library: research-pubs@uow.edu.au 


\title{
HR on the line: Human resource managers' contribution to organisational value and workplace performance
}

\author{
Abstract \\ This article examines the professional identity and role of human resource managers in fostering and \\ implementing strategies that encourage high workplace performance. Workplace performance affects \\ Australian competitiveness and this is the first detailed empirical analysis of Australian HR managers that \\ combines case studies and survey methods. This research seeks to provide more in-depth knowledge \\ and understanding of HR managers and line managers and how the HR function can contribute to high \\ workplace performance. Overall this research suggests that while the HR function is likely to change in \\ the future, its role is not diminishing in organisational decision-making. In particular, the HR function \\ appears to provide an important function in providing the balance between behaviours and performance.

\section{Disciplines \\ Business}

\section{Publication Details} \\ Gollan, P. J. (2012). HR on the line: Human resource managers' contribution to organisational value and \\ workplace performance. Asia Pacific Journal of Human Resources, 50 (3), 288-307.
}




\section{${ }^{1} \mathrm{HR}$ on the line: Human resource managers' contribution to organizational value and workplace performance By Paul J. Gollan ${ }^{2}$}

A relatively under-developed area in HR research both in theory development and empirical data has been the relationship between the $\mathrm{HR}$ function and line management and the value added that the human resource function can contribute to line management performance. The role of line managers has always been central to the concept of HRM. The assignment and devolution of HR responsibilities to line management is often claimed to be one of the defining characteristics of HR. However, the roles of the HR manager and line managers as part of the HR function role are often not clearly thought through. Is sharing such responsibilities a way for HRM specialists to be taken more seriously or does it run the risk of HR specialists losing control over both the process and the outcomes in ways that inhibit, rather than help the firm. In essence, what are the costs, benefits, challenges, issues, and strategies for HR and line managers to partner in the design and delivery of human resource management policies and practices? This paper explores these issues by using interview and survey data in ten leading Australian organisations over the last five years. The AHRI and Australian Research Council sponsored project 'Human Resource Managers' Contribution to Workplace Performance' involved 144 interviews with line managers and HR managers from ten organisations. The $51 \mathrm{HR}$ and 93 line management interviews each lasted between one to two hours. In addition, a survey of nearly 1500 employees was carried out departments covered by the interviews, which was designed to assess employee perceptions and evaluations of management and HR practices in their organisation.

\footnotetext{
${ }^{1}$ This paper is based on a project funded by the Australian Research Council, Australian Human Resource Institute, Australian School of Business and Macquarie University (LP0562132). The author acknowledges the generous research support of Catriona Wingrave, Cathy Ying Xu and Ron Callus.

${ }^{2}$ Dr Paul J. Gollan, Professor of Management, Department of Marketing and Management, Macquarie University.
} 


\section{HR on the line}

A recent article in the Australian Financial Review (Nickless, 19-02-2010: 1) entitled 'HR loses that lovin' feeling' highlighted a new tougher stance by human resource executives and managers. Some companies are turning their backs on so-called 'touchy-feely' human resources initiatives such as cultural change programs. Instead they are focusing on performance measurement processes and increasing technical skills through targeted development as a means to reduce cost and ensuring greater value from staff. A new metrics-driven agenda has been created in many organisations.

In this new environment employees must 'prove their value to the company' in ways that can be measured. This approach has been termed a 'rebalance' from focusing on employee behaviour to how such behavior directly translates into workplace and organisational performance.

The greater influence of the chief financial officer and increased global competition has driven increased accountability and value-led approaches. These pressures have forced the human resource management function to undergo a radical transformation by justifying its role and existence.

Human resource management is transforming itself in three major ways - leadership and culture; development and training; and performance and rewards. This is more than a change of terminology, this is a fundamental change to the expectations and the responsibilities of HR managers and the role of the HR function.

Given this context, a relatively under-developed area in HR research both in theory development and empirical data has been the relationship between the HR function and line management and the value added that the human resource function can contribute to line management performance. The role of line managers has always been central to the concept of HRM. The assignment and devolution of HR responsibilities to line management is often claimed to be one of the defining characteristics of HR. However, the roles of the HR manager and line managers as part of the HR function role are often not clearly thought through. Is sharing such responsibilities a way for HRM specialists to be taken more seriously or does it run the risk of HR specialists losing control over both the process and the outcomes in ways that inhibit, rather than help the firm. In essence, what are the costs, benefits, challenges, issues, and strategies for HR and line managers to partner in the design and delivery of human resource management policies and practices?

The AHRI and Australian Research Council ${ }^{3}$ sponsored project 'Human Resource Managers' Contribution to Workplace Performance' involved 144 interviews with line managers and HR managers from ten organisations. The $51 \mathrm{HR}$ and 93 line management

${ }^{3}$ Australian Research Council Linkage Project (LP0562132) 
interviews each lasted between one to two hours. The Line managers and HR managers were from the same department in each organisation to enable a cascade evaluation of the contribution of HR on line management performance. Themes raised in the HR manager interviews included: role, leadership style, HR function size and structure, role of HR function, articulation into the business, competencies, significance and influence, $H R^{\prime}$ 's impact/outcomes, general identity, values and influence. For line managers the themes included: HR function and articulation into the business, HR competencies, HR significance and HR's contribution/outcomes. (See Appendix 1 and 2 for details).

In addition, a survey of nearly 1500 employees was carried out departments covered by the interviews, which was designed to assess employee perceptions and evaluations of management and HR practices in their organisation.

The organisations in the study were selected on the basis of their reputation for establishing high performance work systems and advanced human resources policies. The firms covered a wide range of work and organisational complexity (e.g. investment banking to core call centre customer service work) across key industries (e.g. manufacturing, hospitality, banking, insurance, professional services, telecommunications and alcoholic beverages)

Table 1 Profiles of the Organisations Involved

\begin{tabular}{|l|l|}
\hline Sector/Industry & Size (No. Employees) \\
\hline Institutional Banking & 35,544 employees \\
\hline Professional Services & 135,000 employees \\
\hline Alcoholic Beverages & 17,600 employees \\
\hline Call centre outsourcing & 2,300 employees \\
\hline Alcoholic Beverages & 1,864 employees \\
\hline Hospitality & 419 employees (77,000 worldwide) \\
\hline Hospitality & 590 employees \\
\hline Telecommunications & 10,225 employees \\
\hline Insurance & 10,000 employees \\
\hline Hospitality & 500 employees \\
\hline
\end{tabular}

\section{Background}

The changes in human resource management have been investigated and discussed in many articles, however, some recent changes towards a more performance driven approach is discussed by Fisher, Dowling and Garnham (1999). They found that the change to this new approach is supported by the senior HR managers according to a National survey results from (AHRI), which "provides clear support that senior HR managers perceive that HR needs to be linked much more closely to organizational strategy and there should be consistency between HR policy areas" Fisher et al (1999: 501). The study suggests that "Their concern to add value to the organization, contribute to the bottom line and support a collaborative style of employee relations is characteristic of underlying unitarist values" (Fisher et al, 1999: 512). 
This approach has been termed a 'rebalance' from focusing on employee behaviour to how such behavior directly translates into the workplace and organizational performance. The new approach represents "a move away from the traditional personnel role towards an HR perspective" for which HR policies needs to be "integrated and strategically focused", Fisher et al (1999: 511). Australian organisations have renamed appropriate departments with a new HR title, and "those senior managers who are responsible for HR matters perceive a role change", Fisher et al (1999: 511). The authors also state that: "Within an environment that expects high levels of employee performance and commitment, the HR function has the potential to make a valuable contribution. In aligning itself with management, however, it may also risk distancing itself from a workforce that may not be able or willing to make the same transition", Fisher et al (1999: 512).

The pressure of change also arises from the changing organizational climate. Bowen and Ostroff (2004) suggest that the greater influence of the chief financial officer and increased global competition has driven increased accountability and value-led approaches, which have forced the human resource function to undergo a radical transformation by justifying its role and existence.

This transformation involves a change in responsibilities and expectations as well as a change of the HR function. Some organizations and managers have traditionally considered the human resource management department as lower status function in the management hierarchy. This is due to a perception of HR's lack of understanding of the business, or more specifically "the numbers". These perceptions are partly due to the lack of clear financial outcomes and value to the business and partly because human resources and related functions often serve an administrative paper shuffling role, rather than a business driven strategic agenda. However, HR has recently moved into a harder approach, away from culture change programs and focused on talent development and a more target driven side. HR has changed in 3 ways: leadership and culture; development and training; and performance and rewards.

Caldwell (2001) looks at HR as a change agent and suggests that the forms it can take are growing in significance and complexity. "This complexity not only reflects the inherent ambiguities of the personnel function and its 'chameleon' nature but also the fact that 'role change and reallocation' is now an intrinsic feature of the personnel function in coping with the realities of relentless organisational change", Caldwell (2001: 51).

Buyens and De Vos (2001) observed shifts in the perceptions of top managers, HR managers and line managers and their perceived value of the HR function. They suggest that "Top, line and HR managers recognise that the added value of the HR function is not restricted to fulfilling the role of a strategic partner. On the other hand, added value is not only created by strategic involvement at the earliest stages of decision-making 
processes; the moment at which the function can deliver value for the organisation will depend on the nature of the strategic issue and on the HR domain." Buyens and De Vos (2001: 83).

Wright, McMahan, Snell and Gerhart's (2001) article compares line and HR executives' perceptions of HR effectiveness, including HR function's service delivery, roles and contributions to the firm. Line managers on average rated the importance of equitable compensation system, performance-based incentives, and staffing/succession planning system items 6 on a 7 point scale. However, "there seems to be less agreement regarding the absolute effectiveness of the function in delivering HR services" Wright (2001: 119). Four significant differences between HR and line executives were found over 15 items: the attraction, development, retention of people (communication, training, and commitment) and HR's strategic involvement (HR initiatives, responsiveness); also, the overall mean was significantly higher for HR. "Thus, it appears that line executives seem to view HR as being best at providing basic HR services but are not quite as impressed with HR's effectiveness in contributing to the business" Wright (2001: 119). Wright (2001) suggests using these results to develop a strategic plan to improve the HR function.

Lachnit (2001) denotes that the biggest discrepancies between ratings of HR and Line managers in Wright (2001) study lies in the strategic aspects. The discrepancies could be a result of poor marketing of HR or the Line management does not carry out HR's programs and suggests that Line manager involvement in program design might reduce this.

Brockett's (2009) study examines Line managers' perception of HR's credibility. This article focuses on research by Roffey Park Institute in which 24 percent of Line managers believe that their HR function adds value to their organization. Out of 1050 managers, 11 percent agreed that HR was "customer-focused". Out of 200 HRM 44 percent did not believe that the HR function was adding value. However, 75 percent said the HR function was 'influential' and 64 percent said that it had 'credibility' with leadership. 81percent of managers thought of HR function as being 'out of touch with the rest of the organisation', 57 percent say HR is 'reactive' and 24 percent say HR is 'proactive'.

Within this context, Caudron's (1999) research reviews the battle between line managers and HR managers. It examines the history of HR's role and how the change has brought pressure to the line mangers with more responsibility. It also highlights that line managers need help with employee relations issues but HR can be seen as taking away line managers' flexibility and will end up trying to work around HR rather than work with them. A suggestion for these problems is that line managers and HR managers come from different cultures, including experience training and objectives. 
McGovern, Gratton, Hope-Hailey, Stiles and Truss's (1997) research examined the devolving HR activities to the line, looking at the "feasibility and viability" of HRM. The findings suggest that Line manager involvement is possible; however their practices in the consistency of implementation vary significantly as well as their "quality of practice between managers" (McGovern et al, 1997: 12). This research found that managers were responsible for implementing a variety of HR policies. However, constraints and limitations experienced by the Line managers give a different outcome to those "sketched by the models of HRM". The article indentified 3 constraints on management practices: limited incentives to get involved, short-term nature of managerial activity, and time constraint due to the "downsizing and delayering" of the organisation (McGovern et al, 1997: 26).

Renwick (2003) looks at line manager involvement in HRM. This study shows that: "the line managers here acknowledge that they shared the completion of HR work with $H R$ (in grievance handling for example), that there was a drive to reduce costs (in the line managing more employees than before) and that a more comprehensive approach to HRM occurred (as the line did handle HRM). There was also a drive to place responsibility for HRM to the line, an in using attempt to increase the speed of decision making, and using the line as an alternative to outsourcing the HR function" (Renwick, 2003: 272).

Hunt and Boxall (1998) look at top human resource specialists 'strategic partners' and self-perceptions of these "top cohort of HR practitioners" Hunt and Boxall (1998: 767), including their qualifications, work histories, role orientations and strategic contributions in NZ business sector. "These 'elite practitioners typically demonstrate a 'dual background' in specialist HR activities and line management, and strongly subscribe to Legge's notion of 'conformist innovation'" Hunt and Boxall (1998: 767). Consistent with this 'dual background', there was no evidence of these senior HR specialists pursuing an exclusive occupational strategy at odds with their corporate citizenship" Hunt and Boxall (1998: 777). The emphasis was on importance of commercial values with most GMs-HR aimed to focus on the business as a whole and its wider environment.

Wright's (2008) exams at how HR interprets their new role and whether the internalization of this model results in an increase in professional identity. The findings suggest that while many gain greater self-esteem and organizational status from the identity and role of business partner/internal consultant, this does not equate to a broader identity as a member of an HR 'profession'. Wright (2008) focuses on how a model of the HR function as a 'business partner' and 'internal consultant' affects the entry barriers demarcating HR activities from rival management functions, as well as the broader occupational identity of HR practitioners themselves. Wright contrasts this with the positive views of Ulrich (1997) and others, where HR is seen as a change agent and an adviser. Most of the respondents saw themselves as a 'trusted adviser' and 'change agent' instead of the traditional bureaucratic vision of HR. Findings also showed that 
those who had successfully attained organizational legitimacy largely rejected identification with a broader HR profession. The study suggests that the business partner and internal consultants appear to be the future for HR.

\section{Summary of results}

\section{HR Mangers}

The interviews with the HR managers revealed a number of important issues regarding their perceptions of their role, level of resources, HR functions effectiveness and identity, how HR contribution is measured and valued and HR managers relationship with line management.

Overwhelmingly, HR managers in these organisations see their role as a strategic partner as well as a functional expert with around 6 in 10 stating that this was their dual role. Junior HR professionals were more likely to see themselves as functional experts then more senior HR managers. (See Table 2)

Table 2 HR Managers' Views on Their Role in the Organisation

\begin{tabular}{|l|l|l|l|l|}
\cline { 2 - 5 } \multicolumn{1}{c|}{} & $\begin{array}{l}\text { ALL } \\
(51)\end{array}$ & $\begin{array}{l}\text { HRD } \\
(12)\end{array}$ & $\begin{array}{l}\text { HRM } \\
(23)\end{array}$ & $\begin{array}{l}\text { JNR } \\
(16)\end{array}$ \\
\hline Strategic partner & $61 \%$ & $83 \%$ & $70 \%$ & $31 \%$ \\
\hline Functional Expert & $55 \%$ & $42 \%$ & $57 \%$ & $63 \%$ \\
\hline Human Capital Development & $43 \%$ & $42 \%$ & $39 \%$ & $50 \%$ \\
\hline Employee advocate & $29 \%$ & $17 \%$ & $39 \%$ & $31 \%$ \\
\hline
\end{tabular}

Note: Respondents can answer more than one category

Within these high performing workplaces nearly 60 percent of HR managers believed that HR leadership and HR policies and practices were aligned in their organisations although 37 percent thought that this was difficult to achieve. Some HR managers suggested that this was due to a lack of financial resources, with two thirds of HR managers stating they had insufficient resources to do their job. Again nearly two thirds indicated that leadership skills from HR were the most important factor for ensuring such alignment.

Interestingly, nine out of ten HR managers indicated that HR had at least some involvement in formulating the business strategy and all our interviewees stated at least some involvement in implementing the business strategy.

A HR Director in a Bank argued:

This issue is about reconfiguring how our products interface with the relationship business, on the face of it, it is about organization design and process flow and 
handovers but it's got a lot to do with people and so we're right in there in those conversations, influencing and shaping things ...

To the question of in practice, do you see HR as an add-on to the business, fully integrated or somewhere in between, over half of HR manager's suggested it was fully integrated in the business (all HR Directors indicated this was the case) although a significant minority (mainly middle HR managers) suggested HR to be somewhere in between.

HR manager's perceptions of effectiveness were also significant. In our sample, HR managers stated that the HR function was good at developing strategies; understanding the business; retention; employee development and communication.

In one of the most important and challenging areas of people management engagement - eight out of ten HR managers believed that the HR function has at least a reasonable influence on engagement although one in five believed that $\mathrm{HR}$ could have more influence.

HR managers also mentioned a number of areas for improvement, such as with retention; communication; engagement, leadership; applying strategies and talent management (See Table 5). Interestingly, while some managers saw retention as a core competence it was also considered by other HR managers as an area for improvement given increasing focus on retention issues in many organisations.

Table 3 HR Managers' Views on Areas for Improvement

\begin{tabular}{|l|l|l|l|l|}
\hline & All & HRD & HRM & JNR \\
& 38 & 12 & 17 & 9 \\
\hline Retention & $13 \%$ & $8 \%$ & $18 \%$ & $11 \%$ \\
\hline Communication & $13 \%$ & $16 \%$ & $18 \%$ & 0 \\
\hline Engagement & $11 \%$ & $16 \%$ & $12 \%$ & 0 \\
\hline Leadership & $11 \%$ & $0 \%$ & $6 \%$ & $11 \%$ \\
\hline Strategies & $11 \%$ & $8 \%$ & $12 \%$ & $11 \%$ \\
\hline Talent management & $11 \%$ & $24 \%$ & $6 \%$ & 0 \\
\hline
\end{tabular}

Note: Respondents can answer more than one category

Previous research has suggested a degree of confusion or an 'identity crisis' among HR professionals which may cause confusion and undermine effectiveness. Our research suggests this is not the case as HR professionals may in fact have "dual identities" in carrying out their role and activities. Nearly 60 percent of HR managers stated that they identified with the organisation they work for as well as the HR function. This was uniform across all levels of HR managers.

\section{$\underline{\text { Line Managers }}$}


Line managers' views of HR were also interesting in terms of HR supporting line management, HR goals, HR function effectiveness and influence on organisational decision making.

Nearly 60 percent of line managers indicated that the main goal for HR was operational while 50 percent stated that the goals of the HR function are to provide support and facilitation. Developing people, performance management, acting as an advisor and developing a culture were also important to some line managers.

Line managers were positive about how HR achieved these goals with 60 percent stating that the HR function was very good at operational tasks in their organisation. Other areas where line managers thought HR function was effective were strategic approach, support and advice to line management and communication.

On a more negative note, 60 percent of line managers said that HR administration limited them in achieving their organisational goals. A majority of line managers also indicated that the HR function could improve its effectiveness by contributing to a more productive relationship between management and employees in their organisation.

Significantly around 70 percent of line managers believed that the HR function was influential on senior management and line management at lower levels in their organisation.

However, around 3 in 10 line managers indicated that they had little or no influence. Representative of this view were the comments by a senior line manager in the hospitality industry when he stated:

Not as influential towards business strategy as they can be. They don't participate either because they do not want to participate or they are not given the opportunity ... when they are, I don't see them making an active participation due to their lack of knowledge about revenue driving strategies ... HR is there to assist and not drive it.

Regarding overall effectiveness, 67 percent of line managers in our sample indicated they were more effective people managers because of the HR function, such as setting deadlines for performance review, with 25 percent not agreeing with the statement.

Some 56 percent believed that their organisation was better placed to face the future because of the HR function. Issues highlighted included training, recruitment, support, engagement, culture and developing employees.

Nearly 60 percent interviewees stated that employees in their organisations are at least to some extent more engaged and committed to the firm as a result of HR. However, around one in four stated that HR does not contribute to this. 
In addition, over six in ten interviewees in our group stated that employees are more skilled and/or productive at least to some extent from HR's role. The rest, four in ten, do not think that HR's role contributes to this.

\section{Employees}

On average, the employees surveyed are marginally or somewhat positive in their perceptions of HR strengths (Factor Mean=3.19), management's caring about employee welfare (Factor Mean=3.33) and employees' trust for HR (Factor Mean=3.51, see Table 4).

However, the opinions are largely varied on most specific aspects amongst individual respondents (as indicated by the levels of standard deviation in Table 4), which indicates the ambiguity and/or variability of HR's role to employees. For example, 42 percent of employees in the survey indicated that their organisation's HR practices contributed to their work satisfaction. A similar percentage (44 percent) also felt that HR policies were clearly communicated to employees. Thirty six percent of employees agree that HR practices did help workers develop their knowledge and skills, while a significant minority of employees saw this as a line management issue.

Surprisingly, nearly 40 percent of employees in the survey did not value good HR practices as an attraction in the recruitment process. Only 18 percent of employees in our sample suggested that line managers did not implement HR policies properly, highlighting the importance of line management in delivering to employees.

Employees generally believe that it's the management of the organisation determines HR and other policies affecting their welfare and actions to be taken (Centralisation Factor Mean $=3.91$ ).

Please note that all attributes are measured on a 5-point Likert scale (Likert 1961) where " 1 " means "strongly disagree" and " 5 " means "strongly agree". All negatively worded scales are reversed for analyses, including calculating factor means. 
Table 4 Employees' Perceptions of HR (One-sample T-test)

(Test value of 3 , where " $1=$ strongly disagree" and " $5=$ strongly agree")

\begin{tabular}{|c|c|c|c|c|c|}
\hline & \multirow[b]{2}{*}{$\mathrm{N}$} & \multirow{2}{*}{$\begin{array}{c}\text { Mean } \\
\text { (M) }\end{array}$} & \multirow{2}{*}{$\begin{array}{l}\text { Std. } \\
\text { Deviation } \\
\text { (SD) }\end{array}$} & \multicolumn{2}{|c|}{$\begin{array}{c}\text { Test value = } 3 \\
\text { "Neither" }\end{array}$} \\
\hline & & & & $\mathrm{t}$ & $\begin{array}{c}\text { Sig. } \\
\text { (2-tailed) }\end{array}$ \\
\hline Management cares well (Factor mean*) & 1350 & 3.33 & 0.80 & 15.35 & 0.000 \\
\hline $\begin{array}{l}\text { Senior management pays little attention to the interests of } \\
\text { employees }\end{array}$ & 1350 & 2.92 & 1.08 & -2.83 & 0.005 \\
\hline $\begin{array}{l}\text { *Senior management pays little attention to the interests of } \\
\text { employees_rev }\end{array}$ & 1350 & 3.08 & 1.08 & 2.83 & 0.005 \\
\hline Senior management cares about employees & 1352 & 3.43 & 0.96 & 16.46 & 0.000 \\
\hline $\begin{array}{l}\text { Senior management tries to be fair in its actions towards } \\
\text { employees }\end{array}$ & 1352 & 3.48 & 0.93 & 19.19 & 0.000 \\
\hline HR strengths (Factor mean*) & 1337 & 3.19 & 0.67 & 10.49 & 0.000 \\
\hline HR practices here contribute to my work satisfaction & 1345 & 3.23 & 0.92 & 9.12 & 0.000 \\
\hline $\begin{array}{l}\text { I was attracted to this company because of its good HR } \\
\text { practices }\end{array}$ & 1346 & 2.82 & 0.96 & -6.85 & 0.000 \\
\hline Managers here don't implement HR policies properly & 1346 & 2.69 & 0.86 & -13.37 & 0.000 \\
\hline *Managers here don't implement HR policies properly_rev & 1346 & 3.31 & 0.86 & 13.37 & 0.000 \\
\hline HR policies here are clearly communicated to employees & 1344 & 3.40 & 0.96 & 15.07 & 0.000 \\
\hline $\begin{array}{l}\text { Managers here adopt a similar approach to managing } \\
\text { employees }\end{array}$ & 1345 & 3.24 & 0.87 & 10.27 & 0.000 \\
\hline $\begin{array}{l}\text { HR practices here make me feel much more confident in my } \\
\text { ability to do my job well }\end{array}$ & 1347 & 3.18 & 0.90 & 7.40 & 0.000 \\
\hline HR practices here help me to achieve my goals & 1346 & 3.19 & 0.92 & 7.65 & 0.000 \\
\hline $\begin{array}{l}\text { HR practices here help me a great deal to develop my } \\
\text { knowledge and skills }\end{array}$ & 1345 & 3.11 & 0.93 & 4.47 & 0.000 \\
\hline Managers here agree on how to implement HR policies & 1345 & 3.27 & 0.82 & 11.90 & 0.000 \\
\hline HR policies at this company are difficult to understand & 1345 & 2.65 & 0.86 & -14.95 & 0.000 \\
\hline${ }^{*} H R$ policies at this company are difficult to understand_rev & 1345 & 3.35 & 0.86 & 14.95 & 0.000 \\
\hline $\begin{array}{l}\text { HR practices don't really make a difference to the way } \\
\text { managers behave here }\end{array}$ & 1346 & 2.95 & 0.96 & -2.11 & 0.035 \\
\hline $\begin{array}{l}\text { *HR practices don't really make a difference to the way } \\
\text { managers behave here_rev }\end{array}$ & 1346 & 3.05 & 0.96 & 2.11 & 0.035 \\
\hline HR practices here help me to achieve the company's goals & 1346 & 3.32 & 0.85 & 13.65 & 0.000 \\
\hline Trust for HR (Factor mean*) & 1327 & 3.51 & 0.71 & 25.93 & 0.000 \\
\hline $\begin{array}{l}\text { HR is prepared to put forward employees' views to line } \\
\text { management }\end{array}$ & 1330 & 3.36 & 0.90 & 14.42 & 0.000 \\
\hline HR tries to be fair & 1329 & 3.72 & 0.83 & 31.58 & 0.000 \\
\hline HR does not have employees interests at heart & 1328 & 2.53 & 0.96 & -17.85 & 0.000 \\
\hline${ }^{*} H R$ does not have employees interests at heart_rev & 1328 & 3.47 & 0.96 & 17.85 & 0.000 \\
\hline Without HR, employees would be worse off & 1330 & 3.63 & 0.98 & 23.33 & 0.000 \\
\hline $\begin{array}{l}\text { Employees can trust } \mathrm{HR} \text { to balance the interests of } \\
\text { management and employees }\end{array}$ & 1330 & 3.37 & 0.96 & 14.02 & 0.000 \\
\hline Centralisation (Factor mean) & 1251 & 3.91 & 0.64 & 49.90 & 0.000 \\
\hline $\begin{array}{l}\text { Most decisions that affect us are made by senior management } \\
\text { Employees here carry out decisions made higher up in the } \\
\text { organisation }\end{array}$ & $\begin{array}{l}1348 \\
1251\end{array}$ & $\begin{array}{l}3.96 \\
3.85\end{array}$ & 0.76 & 39.67 & 0.000 \\
\hline
\end{tabular}

* Note: Negatively worded scales are reversed for analyses, including calculating factor mean. 


\section{Discussion}

In considering HR managers identity, results from Wright (2008) show that most of the respondents saw themselves as a 'trusted adviser' and 'change agent'. In our study, HR managers see their role as a strategic partner as well as a functional expert with around 6 in 10 stating that this was their dual role. This may be because there are differences in what is expected of them and what they actually want to achieve as a HR manager. It seems from the research that these HR managers aspire to be strategic but they are required to fulfill their duties as a functional expert. Wright's study also found that the respondents who had successfully attained organizational legitimacy largely rejected identification with a broader HR profession. In comparison to the present study, the HR managers still identify with being a functional expert as well as the strategic side of the role. This may be because in our study, we are reporting HR as a whole and not focusing on only the HR mangers that have successfully attained organisational legitimacy. However our study did look at the differences between HR directors, HR managers and junior HR managers and found that Junior HR professionals were more likely to see themselves as functional experts, HR managers identified with all roles (Strategic partner, functional expert, human capital developer and employee advocate) and HR directors mainly with the strategic role. This is consistent with Wright in that the higher up and more established HR become; the less identification there is with the functional side of HR.

Hunt and Boxall (1998) found that the HR managers they studied had a 'dual background' in specialist HR activities and line management. This might be connected to the findings in this study which suggest that HR managers have 'dual identities' in carrying out their role and activities. The HR managers in this study identified with the organisation they work for as well as the HR function. This highlights the complexity of the role and the different levels expected of a HR manager. Our study also found that, in considering HR as an add-on to the business, fully integrated or somewhere in between, over half of HR manager's suggested it was fully integrated in the business, this included all HR directors. However there was a significant minority (mainly middle HR managers) suggested HR to be somewhere in between and almost a tenth viewed HR as not fully integrated. This highlights the conflicting views of HR in terms of where they fit in to the business, again showing the difference in opinions between the different levels of HR manager. This might be to do with the way in which the HR role evolves and the different pressures and expectations that are put on the HR manager as he/she becomes more established and experienced.

When looking at the perceptions of HR, the HR managers in our study as a whole perceived the HR function to be good at developing strategies, understanding the business, retention, employee development and communication. The HR directors viewed strategies as the main HR competency, HR managers perceived employee development as their main competency, whereas the junior managers perceived retention and understanding the business as the main competency of the HR function. 
This highlights not only what is stated by Buyens and De Vos, that the HR function adds value in many ways, but that within the HR function the mangers have different views of what their competencies are. This might be to do with their individual roles or how they see HR making a difference, but it seems that there are different views from the different levels of managers within the HR function.

The areas that the respondents viewed needed improvement were retention; communication; engagement, leadership; applying strategies and talent management. Once again, there were differences between the HR directors, HR managers and junior $\mathrm{HR}$ managers. The HR directors viewed talent management to be the main area for improvement, the HR managers viewed retention and communication as the main areas for improvement and the junior HR managers stated leadership, strategies, and retention as their main areas for improvement. This again shows the differences in perceived roles and expectations of the different level of the HR function. The finding also highlights the conflicting views of managers involved, as retention is mentioned as both a positive and negative aspect. This could be explained as being something that is perceived as being good already but also could be performed better.

The biggest discrepancies found in this study and previous research is between the perceptions of HR mangers and line managers when considering HR competencies and areas for improvement in terms of what helps and limits the line. For example in Wright et al (2001) there were four significant differences in perceptions of competency between HR and line management, i.e. attraction, development, retention of people and the HR managers' strategic involvement. In our study, Line managers stated that HR was effective in strategic approach, support and advice to line management and communication. The HR and line managers in our study did agree on developing strategies and communication, however the line management did not state retention, understanding the business or employee development as a main competency.

In Wright (2001) it is suggested from their research that line managers perceive HR to be good at providing basic HR services but need to improve on contributing to the business. In our study, it appears that basic HR services such as administration, are limiting to the line management. Moreover, in comparison to the HR managers' self perceived areas of improvement, there was no mention of these areas by line managers apart from that they could improve on the relations between managers and employees, thus we are not able to pinpoint one specific area that HR need to improve on.

In Brockett's (2009) study, looking at Line managers' perception of HR's credibility, one in four of Line Managers believe that their HR function adds value to their organization. In our study the Line managers were more positive in regarding overall effectiveness; over two thirds of line managers in our sample indicated they were more effective people managers because of the HR function, with one in four not agreeing with the statement. In addition to this, over half of the line managers believed that their organisation was better placed to face the future because of the HR function. Reasons 
highlighted for this included training, recruitment, support, engagement, culture and developing employees. In Wright et al (2008) it is suggested that the discrepancies between HR and Line managers could be a result of poor marketing of HR. Caudron (1999) suggests that problems arising between HR and line managers could come from different cultures, including experience training and objectives From our study, it could be a lack of communication or confusions over the role of HR and what is expected of them.

Brockett found that 75 percent line managers viewed the HR function as 'influential' in general and 64 percent said that it had 'credibility' with leadership. Similarly, nearly two thirds of line managers in our study stated that HR influences the engagement and commitment of employees in their organisations. Our study also found that HR influences employees to a degree in improving their skills and/or productivity. Brockett also found that 57 percent of line managers viewed HR as 'reactive' and 24 percent of line managers perceived HR is 'proactive'. This is something that our study did not examine and could possible extend upon.

Brockett also found that 81 percent of managers thought of HR function as being 'out of touch with the rest of the organisation'. In our study, the employees surveyed generally had somewhat positive views of the HR function and in their respective organisations with over a third of respondents in the survey indicated that their organisation's HR practices contributed to their work satisfaction. A similar number of employees also felt that HR policies were clearly communicated to employees. However, Fisher et al (1999) found that senior HR managers state that HR needs to more involved with organisational strategy and there should be more consistency between HR policy areas. These differences could be because of a number of reasons, for example it is the opinion of only senior HR manager, not of directors or junior staff.

In addition, the varied views of employees on that HR practices contributed to developing employees' knowledge and skills highlights the confusion over the role of HR and its purpose. The literature discussed in the background section of this study suggests that there have been big changes in the HR function therefore the results shown in our study suggest that these changes have caused the role of HR to be unclear.

Finally, only one fifth of employees in our sample suggested that line managers did not implement HR policies properly. Highlighting the importance of line management in delivering to employees, three quarters of those surveyed indicated that most decisions that affected them were those made by senior management. This issue of added pressure on the line is highlighted in Caudron (1999) and suggests that it can be seen as HR taking away the line management's flexibility and being forced to work around HR. McGovern et al (1997) suggests that this may cause the line managers role to alter, possibly creating similar problems to the HR function. However, Renwick (2003) suggests that more responsibility on the line could increase the speed of decision making and be useful an alternative outsource for the HR function. 


\section{Conclusions}

Overall this research suggests that while the HR function is likely to change, it is not playing a diminishing role in organisational decision making. The HR function appears to have acquired a degree of influence in providing the balance between behaviours and performance.

In particular, the HR manager interviews highlight a number of issues. Firstly, HR managers believe that they and the HR function add value to the organization, and a majority of HR Managers believe they and the HR function can also be 'influential' in operational and strategic decisions. We found that the majority of senior HR managers see their role as a strategic partner although junior HR managers see their roles in terms of a functional expert; employee retention and the employee relationship are seen by $\mathrm{HR}$ managers as central to their role. However, a real challenge for the HR function is the lack of resources.

This study found that within our sample, HR managers indicated that HR was good at strategy, understanding the business, retention and employee development although saw room for improvement especially in addressing retention issues, improved communication and engagement with line managers and through the organisation. Notwithstanding this HR managers still saw their main priority as providing administrative tasks and learning and development. Finally, previous research suggests a degree of confusion or an 'identity crisis' with HR professionals. Our research would suggest that this is not the case and HR professionals may in fact have dual identities as a means to satisfy their role, activities and values.

When looking at the results produced from the Line management interviews, several issues were highlighted. In terms of people management, communication, culture and retention were key issues. However there seems to be 'role conflict' over these issues in that there is dispute over who has responsibility over these issues. Our study found that Line managers generally see HR goals in terms of operational terms or providing support rather than strategic goals. However, where HR undertakes a strategic approach, this is considered to be positive. We found that there were some positive and negative issues regarding HR function operational responsibilities. It would seem where this is effective it greatly adds value to line management. However, where it is slow or administrative in delivery it creates concerns with line management. It would seem to be hygiene factor (must get it right) among line management. In regards to the employment relationship, our research found that a minority of line managers believe this is not a HR responsibility. And finally, again there was overwhelming support from the line management in terms of HR contribution to the future of their organisation. Line management was also positive of $\mathrm{HR}$ contribution to instill a more engaged and committed workforce and employees were more skilled and productive because of HR's role. 
While the research focused on organisations with high performance workplace systems and advanced HR practices, the research is clear that the human resource function does have an important and central role in high performing organisations. The true value of human resource management is combining the figures and understanding the blood that runs through the business. Some would call this culture while others would simply see this as the way people do things.

The compliance mentally that drove the systems and institutions of work are now considered by many as outdated and part of past vested interest. This has highlighted the importance of institutions, processes and procedures in changing with the times to capture the future.

The use of sophisticated employee development and training programs to give workers not only opportunities with their employer but in the future provide the necessary security in the brave new market driven world.

Finally, for many employers 'Softer' HR strategies would seem to be replaced by greater focus on performance and technical skills. The capacity of HR Managers and the HR function as a whole is under the spot light. Our research shows the challenge for HR is to step-up to the mark and not only embrace but full integrate this new world of work.

The capacity of HR Managers and the HR function as a whole is under the spot light. Our research shows the challenge for HR is to step up to the mark.

For HR managers, there are challenges, but the opportunities are there for those who recognise them.

Dr Paul J. Gollan FAHRI is a Professor of Management and Director of Research in the Department of Marketing and Management at Macquarie University. He is also a Visiting Professor in the Department of Management at the London School of Economics and was a Chief Investigator on the 'Human Resource Managers Contribution to Workplace Performance' AHRI/ARC Linkage Research Project. 


\section{References}

Bowen, J., and Ostroff, P. 2004. Understanding HRM- firm performance linkages: the role of the "strength" of the HRM system. Academy of Management Review. 29(2): 203221.

Brockett, J. 2009. Line managers question HR's credibility. Available from www.peoplemanagement.co.uk/news, retrieved June $12^{\text {th }}, 2010$.

Buyens, D. and De Vos, A. 2001. Perceptions of the value of the HR function. Human Resource Management Journal. 11(3): 70-89.

Caldwell, R. 2001. Champions, adapters, consultants and synergists: the new change agents in HRM. Human Resource Management Journal, 11(3): 39-52.

Caudron S. 1999. Workforce cover story. HR vs. Managers. August 1999. Available from www.workforceonline.com, retrieved June $12^{\text {th }}, 2010$.

Fisher, C., Dowling, P.J., Garnham, J. 1999. The impact of changes to the human resources function in Australia. The International Journal of Human Resource Management, 10(3) June: 501-514.

Hunt J. and Boxall P. 1998. Are top human resource specialists 'strategic partners'? Selfperceptions of a corporate elite. The International Journal of Human Resource Management, 9(5): 767-781.

Lachnit C. 2001. 'Why HR don't get no respect'. Between the lines. Workforce, December.

Legge, K. 1995. 'HRM: rhetoric, reality and hidden agendas'. In Storey, J. (Ed.), Human Resource Management: A Critical Text. London: Routledge.

Likert, R. 1961. New Patterns of Management, New York: McGraw Hill.

McGovern P., Gratton L., Hope-Hailey V., Stiles P. and Truss C. 1997. Human resource management on the line? Human Resource Management Journal. 7(4): 12-29.

Nickless, R. 2010. HR loses that lovin' feeling, Australian Financial Review, 19 February: p. 1.

Ostroff, C., \& Schmitt, N. 1993. Configurations of organizational effectiveness and efficiency. Academy of Management Journal, 36(6): 1345-1361. 
Renwick D. 2003. Line manager involvement in HRM: an inside view. Employee

Relations. 25(3): 262-280

Ulrich, D. 1997. Human Resource Champions. Boston: Harvard University Press.

Wright C. 2008. Reinventing human resource management: Business partners, internal consultants and the limits to professionalization. Human Relations, 61(8): 1063-1086.

Wright P. M., McMahan, G. C., Snell, S.A. and Gerhart, B. 2001. Comparing line and HR executives' perceptions of the HR effectiveness: services, roles, and contributions.

Human resource Management. (Summer) 40(2): 111-123. 


\section{Appendix 1}

\begin{tabular}{|c|c|c|c|c|c|c|c|}
\hline & Gender & Age & Position & $\begin{array}{l}\text { Company } \\
\text { tenure }\end{array}$ & $\begin{array}{c}\mathrm{HR} \\
\text { tenure }\end{array}$ & Industry & $\begin{array}{l}\text { Tenure in } \\
\text { Industry }\end{array}$ \\
\hline 1 & $\mathrm{M}$ & $41-45$ & HR director & $1-2$ & $7-8$ & Professional Services & $1-2$ \\
\hline 2 & $\mathrm{M}$ & $51-55$ & HR director & $17-18$ & $17-18$ & Alcoholic beverages & $15-16$ \\
\hline 3 & $M$ & $31-35$ & HR director & $5-6$ & $9-10$ & Institutional Banking & $5-6$ \\
\hline 4 & $\mathrm{~F}$ & $36-40$ & HR Manager & $7-8$ & $15-16$ & Alcoholic beverages & $7-8$ \\
\hline 5 & $\mathrm{~F}$ & $31-35$ & Junior HR & $3-4$ & $5-6$ & Alcoholic beverages & $3-4$ \\
\hline 6 & $\mathrm{~F}$ & $25-30$ & Junior HR & $3-4$ & $7-8$ & Professional Services & $3-4$ \\
\hline 7 & $\mathrm{M}$ & $46-50$ & HR Manager & $1-2$ & $9-10$ & Alcoholic beverages & $5-6$ \\
\hline 8 & $M$ & $51-55$ & Former HR director/now HRM & $13-14$ & $11-12$ & Alcoholic beverages & $13-14$ \\
\hline 9 & $\mathrm{~F}$ & $25-30$ & HR Business Partner & $1-2$ & $5-6$ & Insurance & $1-2$ \\
\hline 10 & $\mathrm{M}$ & $56-60$ & HR director & $13-14$ & $29-30$ & Alcoholic beverages & $19-20$ \\
\hline 11 & $\mathrm{M}$ & $36-40$ & HR Manager & $3-4$ & $13-14$ & Alcoholic beverages & $3-4$ \\
\hline 12 & $\mathrm{M}$ & $41-45$ & Marketing Capability Leader & $13-14$ & $1-2$ & Alcoholic beverages & $13-14$ \\
\hline 13 & $\mathrm{~F}$ & $41-45$ & HR Manager & $1-2$ & $9-10$ & Professional Services & $1-2$ \\
\hline 14 & $\mathrm{~F}$ & $<25$ & Junior HR & $3-4$ & $1-2$ & Hospitality & $3-4$ \\
\hline 15 & $\mathrm{M}$ & $36-40$ & HR director & $3-4$ & $7-8$ & Professional Services & $3-4$ \\
\hline 16 & $\mathrm{~F}$ & $25-30$ & HR Manager & $1-2$ & $5-6$ & Alcoholic beverages & $1-2$ \\
\hline 17 & $\mathrm{~F}$ & $25-30$ & HR Manager & $7-8$ & $7-8$ & Professional Services & $7-8$ \\
\hline 18 & $\mathrm{~F}$ & $36-40$ & Head of People Capital & $3-4$ & $3-4$ & Institutional Banking & $3-4$ \\
\hline 19 & $\mathrm{~F}$ & $36-40$ & HR director & $3-4$ & $7-8$ & Hospitality & $19-20$ \\
\hline 20 & $\mathrm{~F}$ & $25-30$ & HR Manager & $1-2$ & $3-4$ & Call centre outsourcing & $1-2$ \\
\hline 21 & $\mathrm{M}$ & $46-50$ & HR Manager & $11-12$ & $11-12$ & Alcoholic beverages & $11-12$ \\
\hline 22 & $\mathrm{M}$ & $25-30$ & HR Administrator & $<1$ & $<1$ & Hospitality & $<1$ \\
\hline 23 & $\mathrm{~F}$ & $31-35$ & Junior HR & $3-4$ & $5-6$ & Hospitality & $9-10$ \\
\hline 24 & $\mathrm{~F}$ & $31-35$ & HR Manager & $3-4$ & $15-16$ & Telecommunications & $3-4$ \\
\hline 25 & $\mathrm{M}$ & $46-50$ & HR Manager & $23-24$ & $9-10$ & Alcoholic beverages & $19-20$ \\
\hline 26 & $\mathrm{~F}$ & $25-30$ & HR Manager & $5-6$ & $5-6$ & Alcoholic beverages & $5-6$ \\
\hline 27 & $\mathrm{~F}$ & $25-30$ & HR Manager & $9-10$ & $7-8$ & Call centre outsourcing & $9-10$ \\
\hline 28 & $\mathrm{M}$ & $25-30$ & Senior HR Manager & $3-4$ & $3-4$ & Hospitality & $5-6$ \\
\hline 29 & $\mathrm{~F}$ & $25-30$ & HRM Operations & $1-2$ & $1-2$ & Alcoholic beverages & $1-2$ \\
\hline 30 & $\mathrm{~F}$ & $<25$ & HR Manager & $1-2$ & $<1$ & Insurance & $1-2$ \\
\hline 31 & $\mathrm{~F}$ & $31-35$ & Senior HR Manager & $3-4$ & $3-4$ & Professional Services & $3-4$ \\
\hline 32 & $\mathrm{~F}$ & $<25$ & Junior HR & $1-2$ & $1-2$ & Hospitality & $1-2$ \\
\hline 33 & $\mathrm{M}$ & $56-60$ & HR director & $13-14$ & $3-4$ & Institutional Banking & $3-4$ \\
\hline 34 & $\mathrm{M}$ & $36-40$ & HR Manager & $1-2$ & $21-22$ & Telecommunications & $1-2$ \\
\hline 35 & $\mathrm{~F}$ & $31-35$ & Junior HR & $13-14$ & $3-4$ & Hospitality & $13-14$ \\
\hline 36 & $\mathrm{~F}$ & $25-30$ & Junior HR & $1-2$ & $9-10$ & Alcoholic beverages & $1-2$ \\
\hline 37 & $\mathrm{~F}$ & $31-35$ & HR director & $3-4$ & $5-6$ & Hospitality & $9-10$ \\
\hline 38 & $\mathrm{~F}$ & $31-35$ & HR director & $1-2$ & $11-12$ & Hospitality & $1-2$ \\
\hline 39 & $\mathrm{~F}$ & $36-40$ & HR Manager & $1-2$ & $1-2$ & Call centre outsourcing & $19-20$ \\
\hline 40 & $\mathrm{~F}$ & $25-30$ & HR coordinator & $1-2$ & $1-2$ & Hospitality & $1-2$ \\
\hline 41 & $\mathrm{~F}$ & $25-30$ & HR Manager & $1-2$ & $9-10$ & Professional Services & $1-2$ \\
\hline 42 & $\mathrm{~F}$ & $31-35$ & Junior HR & $<1$ & $3-4$ & Institutional Banking & $11-12$ \\
\hline 43 & $\mathrm{~F}$ & $25-30$ & HR Manager & $1-2$ & $7-8$ & Professional Services & $5-6$ \\
\hline 44 & $\mathrm{M}$ & $31-35$ & HR director & $5-6$ & $9-10$ & Telecommunications & $5-6$ \\
\hline 45 & $\mathrm{~F}$ & $36-40$ & Junior HR & $13-14$ & $<1$ & Telecommunications & $13-14$ \\
\hline 46 & $\mathrm{~F}$ & $46-50$ & Senior HR Manager & $3-4$ & $17-18$ & Insurance & $3-4$ \\
\hline 47 & $\mathrm{~F}$ & $25-30$ & HR Manager & $5-6$ & $5-6$ & Insurance & $5-6$ \\
\hline 48 & $\mathrm{~F}$ & $31-35$ & Senior HR Manager & $13-14$ & $13-14$ & Alcoholic beverages & $13-14$ \\
\hline 49 & $\mathrm{~F}$ & $31-35$ & HR Manager & $1-2$ & $5-6$ & Hospitality & $11-12$ \\
\hline 50 & $\mathrm{M}$ & $51-55$ & HR director & $5-6$ & $15-16$ & Insurance & $5-6$ \\
\hline 51 & $\mathrm{~F}$ & $41-45$ & HR director & $1-2$ & $13-14$ & Call centre outsourcing & $1-2$ \\
\hline
\end{tabular}




\section{Appendix 2}

\begin{tabular}{|c|c|c|c|c|c|c|}
\hline & Age & Company Tenure & Gender & Industry & $\begin{array}{l}\text { Industry } \\
\text { Tenure }\end{array}$ & Position \\
\hline 1 & $25-30$ & $1-2$ & $\mathrm{~F}$ & Hospitality & $9-10$ & $\begin{array}{c}\text { Altitude restaurant } \\
\text { Manager }\end{array}$ \\
\hline 2 & $36-40$ & $<1$ & $\mathrm{M}$ & Hospitality & $15-16$ & Resident Manager \\
\hline 3 & $31-35$ & $<1$ & $\mathrm{M}$ & Call Centre Outsourcer & $3-4$ & Operations Manager \\
\hline 4 & $41-45$ & $21-22$ & $\mathrm{M}$ & Alcoholic Beverages & Unassigned & Compliance Director \\
\hline 5 & Unassigned & $5-6$ & $\mathrm{M}$ & Alcoholic Beverages & $5-6$ & General Manager \\
\hline 6 & $25-30$ & $5-6$ & M & Hospitality & $5-6$ & $\begin{array}{c}\text { Assistant Executive } \\
\text { Housekeeper }\end{array}$ \\
\hline 7 & $41-45$ & Unassigned & $\mathrm{M}$ & Professional Services & Unassigned & National Finance \\
\hline 8 & $36-40$ & $21-22$ & $\mathrm{M}$ & Hospitality & $21-22$ & Chief engineer \\
\hline 9 & $46-50$ & $5-6$ & $\mathrm{M}$ & Alcoholic Beverages & $9-10$ & General Manager \\
\hline 10 & $46-50$ & $5-6$ & M & Alcoholic Beverages & $5-6$ & $\begin{array}{c}\text { General manager } \\
\text { finance }\end{array}$ \\
\hline 11 & $36-40$ & $7-8$ & $\mathrm{M}$ & Alcoholic Beverages & $19-20$ & General Manager \\
\hline 12 & $41-45$ & $5-6$ & $\mathrm{M}$ & Hospitality & Unassigned & Resident Manager \\
\hline 13 & $25-30$ & $11-12$ & $\mathrm{M}$ & Insurance & $11-12$ & Operations Manager \\
\hline 14 & $41-45$ & $1-2$ & $\mathrm{~F}$ & Institutional Banking & $21-22$ & $\begin{array}{l}\text { MD Corp \& } \\
\text { Structured Finance }\end{array}$ \\
\hline 15 & $31-35$ & Unassigned & $\mathrm{M}$ & Alcoholic Beverages & Unassigned & Field sales manager \\
\hline 16 & $36-40$ & $7-8$ & $\mathrm{M}$ & Telecommunication & $7-8$ & General Manager \\
\hline 17 & $41-45$ & $1-2$ & $\mathrm{~F}$ & Institutional Banking & $21-22$ & $\begin{array}{c}\text { Head of Structured } \\
\text { Dept. }\end{array}$ \\
\hline 18 & $41-45$ & $<1$ & $\mathrm{~F}$ & Institutional Banking & $15-16$ & $\begin{array}{l}\text { Head Corporate \& } \\
\text { Hybrid Origination }\end{array}$ \\
\hline 19 & Unassigned & $9-10$ & $\mathrm{~F}$ & Hospitality & $19-20$ & $\begin{array}{c}\text { Housekeeping } \\
\text { supervisor }\end{array}$ \\
\hline 20 & $36-40$ & $1-2$ & $\mathrm{M}$ & Insurance & Unassigned & Head of Claims \\
\hline 21 & $25-30$ & $5-6$ & M & Hospitality & $5-6$ & $\begin{array}{c}\text { Asst Front Office } \\
\text { Manager }\end{array}$ \\
\hline 22 & $36-40$ & $3-4$ & $\mathrm{M}$ & Alcoholic Beverages & $3-4$ & Production Manager \\
\hline 23 & $41-45$ & $7-8$ & $\mathrm{~F}$ & Call Centre Outsourcer & 7-8 & $\begin{array}{c}\text { Chief Operating } \\
\text { Officer }\end{array}$ \\
\hline 24 & $31-35$ & $9-10$ & $\mathrm{M}$ & Professional Services & $9-10$ & Unassigned \\
\hline 25 & Unassigned & $1-2$ & $\mathrm{M}$ & Alcoholic Beverages & $13-14$ & Operations Manager \\
\hline 26 & $51-55$ & $13-14$ & M & Alcoholic Beverages & $13-14$ & $\begin{array}{c}\text { OHS \& Welfare } \\
\text { Manager }\end{array}$ \\
\hline 27 & $36-40$ & Unassigned & $\mathrm{M}$ & Alcoholic Beverages & Unassigned & Managing director \\
\hline 28 & $41-45$ & Unassigned & $\mathrm{F}$ & Professional Services & Unassigned & Consulting Director \\
\hline 29 & $36-40$ & $3-4$ & $\mathrm{M}$ & Hospitality & $19-20$ & $\begin{array}{l}\text { Food and beverage } \\
\text { Director }\end{array}$ \\
\hline 30 & $36-40$ & $11-12$ & $\mathrm{M}$ & Insurance & $11-12$ & Team manager \\
\hline 31 & $41-45$ & $3-4$ & $\mathrm{M}$ & Hospitality & Unassigned & Duty Manager \\
\hline 32 & $36-40$ & $7-8$ & $\mathrm{M}$ & Institutional Banking & $7-8$ & Executive Director \\
\hline 33 & $46-50$ & $5-6$ & $\mathrm{M}$ & Alcoholic Beverages & $19-20$ & Operations Director \\
\hline 34 & $31-35$ & $1-2$ & $\mathrm{M}$ & Telecommunication & $7-8$ & Commercial Director \\
\hline 35 & $41-45$ & $23-24$ & $\mathrm{M}$ & Alcoholic Beverages & $23-24$ & CFO \\
\hline 36 & $25-30$ & $<1$ & $\mathrm{~F}$ & Hospitality & $11-12$ & Cortile Manager \\
\hline 37 & $36-40$ & $9-10$ & $\mathrm{M}$ & Alcoholic Beverages & $9-10$ & General Manager \\
\hline 38 & $41-45$ & $1-2$ & M & Hospitality & Unassigned & $\begin{array}{c}\text { Assistant Executive } \\
\text { Housekeeper }\end{array}$ \\
\hline 39 & $46-50$ & $3-4$ & $\mathrm{M}$ & Hospitality & $19-20$ & General Manager \\
\hline 40 & $41-45$ & $3-4$ & M & Hospitality & $21-22$ & $\begin{array}{l}\text { Assistant Food + } \\
\text { Beverage Director }\end{array}$ \\
\hline 41 & $31-35$ & $1-2$ & $\mathrm{~F}$ & Hospitality & $19-20$ & Executive chef \\
\hline 42 & $31-35$ & $1-2$ & $\mathrm{~F}$ & Institutional Banking & $11-12$ & $\begin{array}{c}\text { Head of Dept Capital } \\
\text { Markets }\end{array}$ \\
\hline 43 & $25-30$ & $3-4$ & $\mathrm{M}$ & Professional Services & $3-4$ & General Manager \\
\hline 44 & $41-45$ & Unassigned & $\mathrm{F}$ & Telecommunication & Unassigned & $\begin{array}{c}\text { Director Organisation } \\
\text { Renewal }\end{array}$ \\
\hline 45 & $25-30$ & $5-6$ & $\mathrm{~F}$ & Professional Services & $5-6$ & General Manager \\
\hline 46 & $51-55$ & Unassigned & $\mathrm{F}$ & Hospitality & $25-26$ & Managing director \\
\hline
\end{tabular}




\begin{tabular}{|c|c|c|c|c|c|c|}
\hline 47 & $41-45$ & $1-2$ & M & Alcoholic Beverages & $1-2$ & $\begin{array}{c}\text { Packaging + Winery } \\
\text { Manager }\end{array}$ \\
\hline 48 & $25-30$ & $7-8$ & M & Hospitality & $15-16$ & $\begin{array}{c}\text { Food + bev. Service } \\
\text { manager }\end{array}$ \\
\hline 49 & Unassigned & Unassigned & M & Hospitality & $15-16$ & $\begin{array}{c}\text { Executive } \\
\text { housekeeper }\end{array}$ \\
\hline 50 & $25-30$ & Unassigned & $\mathrm{F}$ & Hospitality & $5-6$ & $\begin{array}{c}\text { Front office duty } \\
\text { manager }\end{array}$ \\
\hline 51 & $25-30$ & $9-10$ & $\mathrm{~F}$ & Telecommunication & $9-10$ & Marketing Manager \\
\hline 52 & $25-30$ & $1-2$ & $\mathrm{M}$ & Insurance & $7-8$ & Team manager \\
\hline 53 & $36-40$ & $19-20$ & $\mathrm{M}$ & Alcoholic Beverages & $19-20$ & CEO \& Chairman \\
\hline 54 & $25-30$ & $13-14$ & $\mathrm{~F}$ & Professional Services & $13-14$ & $\begin{array}{c}\text { Enterprise Risk } \\
\text { Services - Director }\end{array}$ \\
\hline 55 & $31-35$ & $9-10$ & $\mathrm{~F}$ & Call Centre Outsourcer & $9-10$ & General Manager \\
\hline 56 & $46-50$ & $5-6$ & $\mathrm{~F}$ & Insurance & $5-6$ & Team manager \\
\hline 57 & $41-45$ & $15-16$ & $\mathrm{M}$ & Alcoholic Beverages & $15-16$ & Managing director \\
\hline 58 & $31-35$ & $1-2$ & M & Hospitality & $1-2$ & $\begin{array}{c}\text { Front office duty } \\
\text { manager }\end{array}$ \\
\hline 59 & Unassigned & $9-10$ & M & Alcoholic Beverages & $9-10$ & $\begin{array}{l}\text { Regional Sales and } \\
\text { Customer Service }\end{array}$ \\
\hline 60 & $46-50$ & $1-2$ & $\mathrm{~F}$ & Call Centre Outsourcer & $1-2$ & Team manager \\
\hline 61 & $51-55$ & 13-14 & $\mathrm{M}$ & Hospitality & $25-26$ & General Manager \\
\hline 62 & $31-35$ & $9-10$ & $\mathrm{~F}$ & Hospitality & $9-10$ & Front Office Manager \\
\hline 63 & Unassigned & $27-28$ & M & Alcoholic Beverages & $27-28$ & $\begin{array}{c}\text { International Sales } \\
\text { Director }\end{array}$ \\
\hline 64 & $25-30$ & $1-2$ & $\mathrm{~F}$ & Call Centre Outsourcer & $1-2$ & Operations Manager \\
\hline 65 & Unassigned & $7-8$ & $\mathrm{M}$ & Alcoholic Beverages & $7-8$ & Managing director \\
\hline 66 & $41-45$ & $9-10$ & $\mathrm{M}$ & Telecommunication & $9-10$ & Managing director \\
\hline 67 & $36-40$ & $9-10$ & $\mathrm{~F}$ & Alcoholic Beverages & $11-12$ & $\begin{array}{c}\text { Business Solutions } \\
\text { Manager }\end{array}$ \\
\hline 68 & $46-50$ & $1-2$ & $\mathrm{M}$ & Telecommunication & $9-10$ & Sales Director \\
\hline 69 & Unassigned & 17-18 & $\mathrm{M}$ & Alcoholic Beverages & $9-10$ & Packaging Manager \\
\hline 70 & $31-35$ & $1-2$ & M & Alcoholic Beverages & $1-2$ & $\begin{array}{c}\text { Chief Information } \\
\text { Officer }\end{array}$ \\
\hline 71 & $46-50$ & $15-16$ & M & Alcoholic Beverages & $15-16$ & $\begin{array}{l}\text { International Market } \\
\text { Services Manager }\end{array}$ \\
\hline 72 & $51-55$ & Unassigned & $\mathrm{M}$ & Insurance & $29-30$ & Operations Manager \\
\hline 73 & $46-50$ & Unassigned & M & Alcoholic Beverages & $29-30$ & $\begin{array}{l}\text { Regional Supply } \\
\text { Chain Director }\end{array}$ \\
\hline 74 & $31-35$ & $3-4$ & $\mathrm{M}$ & Call Centre Outsourcer & $3-4$ & CFO \\
\hline 75 & $36-40$ & $3-4$ & M & Institutional Banking & $21-22$ & $\begin{array}{c}\text { Head of Strategy and } \\
\text { Operations }\end{array}$ \\
\hline 76 & $25-30$ & $5-6$ & $\mathrm{M}$ & Call Centre Outsourcer & $5-6$ & Group team leader \\
\hline 77 & $41-45$ & $9-10$ & $\mathrm{~F}$ & Call Centre Outsourcer & $9-10$ & Operations Manager \\
\hline 78 & $51-55$ & $1-2$ & - & Hospitality & $13-14$ & Financial Controller \\
\hline 79 & $31-35$ & $3-4$ & - & Hospitality & $5-6$ & $\begin{array}{c}\text { Asst Front Office } \\
\text { Manager }\end{array}$ \\
\hline 80 & $51-55$ & $33-34$ & $\mathrm{M}$ & Alcoholic Beverages & 33-34 & Managing director \\
\hline 81 & $56-60$ & $3-4$ & $\mathrm{M}$ & Alcoholic Beverages & $3-4$ & General Manager \\
\hline 82 & Unassigned & $1-2$ & $\mathrm{M}$ & Alcoholic Beverages & $1-2$ & Sales Director \\
\hline 83 & $41-45$ & $11-12$ & $\mathrm{M}$ & Telecommunication & $11-12$ & Marketing Manager \\
\hline 84 & Unassigned & $7-8$ & $\mathrm{~F}$ & Insurance & $9-10$ & CFO \\
\hline 85 & $46-50$ & $21-22$ & $\mathrm{~F}$ & Insurance & $25-26$ & Operations Manager \\
\hline 86 & $36-40$ & $1-2$ & M & Institutional Banking & $15-16$ & $\begin{array}{c}\text { Director Portfolio } \\
\text { Management }\end{array}$ \\
\hline 87 & $36-40$ & $17-18$ & $\mathrm{M}$ & Alcoholic Beverages & $17-18$ & Managing director \\
\hline 89 & $31-35$ & $5-6$ & $\mathrm{M}$ & Professional Services & $13-14$ & Consulting-Partner \\
\hline 90 & $51-55$ & $25-26$ & $\mathrm{M}$ & Alcoholic Beverages & $25-26$ & General Manager \\
\hline 91 & $46-50$ & Unassigned & $\mathrm{M}$ & Hospitality & $27-28$ & Financial Director \\
\hline 92 & $25-30$ & $<1$ & $\mathrm{M}$ & Telecommunication & $1-2$ & Operations Manager \\
\hline 93 & $36-40$ & $15-16$ & $\mathrm{~F}$ & Hospitality & $15-16$ & $\begin{array}{c}\text { Housekeeping shift } \\
\text { leader }\end{array}$ \\
\hline
\end{tabular}

